\title{
Happiness, Despair and Education
}

\author{
PETER ROBERTS \\ University of Canterbury, New Zealand
}

\begin{abstract}
In today's world we appear to place a premium on happiness. Happiness is often portrayed, directly or indirectly, as one of the key aims of education. To suggest that education is concerned with promoting unhappiness or even despair would, in many contexts, seem outlandish. This paper challenges these widely held views. Focusing on the work of the great Russian writer, Fyodor Dostoevsky, I argue that despair, the origins of which lie in our reflective consciousness, is a defining feature of human life. Education, I suggest, should not be seen as a flight from despair but as a process of deepening our understanding of suffering and its potentially pivotal role in our humanisation. In developing these ideas, I draw on Kierkegaard's The Sickness Unto Death and Unamuno's The Tragic Sense of Life in Men and Nations, among other sources.
\end{abstract}

Keywords: Existentialism, despair, happiness, consciousness, Dostoevsky, Kierkegaard, Unamuno

\section{Introduction}

In the contemporary Western world, there is an obsession with 'happiness'. Everyone, it seems, is expected to seek happiness and to avoid situations that might lead to unhappiness. Consistent with the wider process of marketisation, happiness has become a commodity: something to be sold, advertised and consumed. Educationists, while often critical of broader social and economic trends, have for the most part accepted the centrality of happiness for human life, and have typically espoused teaching and learning goals and objectives consistent with this view. Nel Noddings has argued: 'Happiness and education are, properly, intimately related. Happiness should be an aim of education, and a good education should contribute significantly to personal and collective happiness' (Noddings, 2003, p. 1). Alternative terms have sometimes been employed to describe what is at stake in establishing desirable educational arrangements - reference might be made, for example, to being 'well adjusted' or having 'high self-esteem', or to achieving a sense of 'well being', or to the development of a 'positive outlook' - but the underlying assumptions in each case are frequently the same. It is taken as given that education should make us feel better, not worse, and that teachers have a responsibility to prepare students to become happy, well integrated, contributing citizens in their lives beyond schools. 
The idea that education is, at least in part, concerned with promoting unhappiness - and perhaps even despair - is very much at odds with the dominant trends of our time. Of course, acknowledgement that some students are not happy is commonplace, and educationists have gone to considerable lengths to understand the causes of such unhappiness and to respond positively to such situations. Where students are unhappy - and this may be in kindergartens, schools, or tertiary education institutions - we seek to address this as a 'problem' with 'solutions' that can range from changing subjects or classes, to acquiring new friends or interests, to counselling, and, increasingly, to drugs. Seldom will the ailment be identified precisely as 'despair', but where this is the case, it will usually be taken for granted that such a state must be overcome and avoided. Despair, where it is examined at all, will often be seen as the very anti-thesis of happiness, and education will be regarded as a means to lift us from this profound form of unhappiness to a more desirable state of mind. To say that one is being well educated yet existing in a state of despair would thus seem to be a contradiction in terms. The movement, as it is often depicted, should be from despair to hope - hope for a mode of being, or a set of psychological and behavioural attributes, or a social system where despair no longer figures prominently. ${ }^{1}$

It is possible, however, to see despair, happiness and education in a somewhat different light, and this will be the task of the present paper. Existentialists, from Kierkegaard onwards, have contributed much to our understanding of despair and its significance in the formation of the human being. Situating the discussion in this longstanding tradition of existentialist thought, ${ }^{2}$ I shall argue that despair need not be seen an aberrant state from which we should seek to escape; rather, it is a key element of any well lived human life. Education, I maintain, is meant to create a state of discomfort, and to this extent may also make us unhappy, but is all the more important for that. Contrary to the spirit of our age, this paper suggests that apparent happiness can be dehumanising. To be educated is, in part, to be aware of one's despair, accepting of it, and able to work productively with it.

I develop this argument via the work of Fyodor Dostoevsky, whose influence on later existentialist writers has been well recognised (see, for example, Kaufmann, 1975; Marino, 2004). I focus on two texts in particular: one, the extraordinarily influential novel, Notes from Underground (Dostoevsky, 2004); the other, the less well known story, ‘The Dream of a Ridiculous Man' (Dostoevsky, 1997). The former was published in 1864, and served as a kind of philosophical precursor to the great novels that were to follow: Crime and Punishment, The Idiot, Demons, and The Brothers Karamazov (Dostoevsky, 1993, 2001, 1994 and 1991 respectively). ${ }^{3}$ The latter first appeared in Dostoevsky's A Writer's Diary (Dostoevsky, 2009) near the end of his life. Together, these two works capture Dostoevsky's final assessment of the human condition (Magarshack, 2001). It is a vision that is both tragic and hopeful. ${ }^{4}$

\footnotetext{
1 There is surprisingly little philosophical work on the significance of despair in educational life. Notable exceptions include Liston (2000), McKnight (2004), and Nielson (2006).

${ }^{2}$ Useful overviews of existentialism can be found in Barrett (1990), Cooper (1999), and Flynn (2009).

${ }^{3}$ For an exhaustive account of Dostoevsky's life and work, see Frank (2010).

${ }^{4}$ In developing the argument in this paper I draw on ideas from Kierkegaard and Unamuno but in a strictly limited way. The point of the paper is not to provide an in-depth analysis of the work of these thinkers; they are employed to inform aspects of the discussion, but the primary purpose is to consider what we can learn from the two texts by Dostoevsky that might be helpful in addressing questions of happiness and despair in education.
} 


\section{Tales from beneath and beyond}

Of all the novels for which Dostoevsky has become known, Notes from Underground is perhaps the most distinctive in its structure and content. There are two parts to the book. In Part One, simply entitled 'Underground', an anonymous narrator, confessing his wickedness (Dostoevsky, 2004, p. 5), presents a diatribe against the philosophy advanced by a group of unnamed 'gentlemen'. His addressees, we know from Dostoevsky's other writings, are the 'rational egoists', a group of reformists headed by Nikolai Chernyshevsky whose ideas captured the Russian imagination in the middle of the $19^{\text {th }}$ century. The philosophy of rational egoism, as set out in Chernyshevsky's book What is to be Done? (Chernyshevsky, 1989) and other works, posited that human actions and choices are determined by self-interest. Rational egoists held that enlightened pursuit of one's own interests was compatible with a love of humankind and would lead to the development of a happier, more harmonious society.

Against the 'scientific' certainty of rational egoism, the Underground Man asserts the importance of human willing and unpredictability. He wants to protect his right to say 'no', even if this means suffering. Human beings, the Underground Man shows, have frequently acted against their best interests, and they are often profoundly irrational in their character. Reason, the Underground Man declares, knows only what it has managed to learn. Reason has its limits, and this must be acknowledged in considering social ideals. The Underground Man's wish is to exist in a manner that will not merely satisfy his reasoning intellect but fulfil his whole capacity for living. It is, he claims, our individuality - our distinctive personal attributes, no matter how apparently 'negative' they may be - that we should want to maintain, and reason may or may not be a dominant element of living on these terms. The features of human life that matter most, the Underground Man implies, are precisely those that lend themselves least well to 'scientific' planning, development and measurement (Dostoevsky, 2004, pp. 5-38).

The second part, 'Apropos of the Wet Snow', gives an account of three sets of events in the narrator's life. The first involves a plot by the Underground Man to bump into an officer he feels has wronged him. The need for this revenge was occasioned, in the Underground Man's mind, by the indifference of the officer towards him when the possibility of a fight presents itself in a bar. When faced with the Underground Man blocking his way, the officer simply lifts him by the shoulders and moves him aside. The Underground Man seeks a remedy for his humiliation by planning, in great detail, a scenario where he will hold his line on a public walkway and bump into the officer. After careful preparation, including the purchase of new clothes especially for the event, he completes his manoeuvre and asserts his rapture at having done so (pp. 47-53).

The second key episode focuses on the Underground Man's brief renewal of an association with a group of school acquaintances. His school fellows are organising a dinner to farewell one of their number. They regard the Underground Man as an object of scorn, barely worthy of any attention except by way of ridicule, but after some reluctance allow him to attend the dinner. The evening proves disastrous for the Underground Man, who is either ignored or treated with mockery and derision. All drink heavily, and the Underground Man can longer contain himself, launching into an angry speech, the incoherence of which he is painfully aware as he proceeds. Crushed by the contempt of his colleagues, he withdraws from 
them and is left to stew in his thoughts. He works himself into a sweat, pacing about on his own in a state of extreme agitation, while the others spend their time in relaxed merriment. His emotions swinging wildly, he suddenly implores the others to forgive him, to which they respond with further mockery. The others depart for a brothel, and eventually the Underground Man too makes his way there, only to find his tormenters have left (pp. 57-80).

The final episode in Part Two of the book then unfolds when the Underground Man meets Liza, a prostitute, with whom he strikes up a conversation. After asking Liza a series of questions about her background, the Underground Man gives her a lecture on the dangers of her profession and then waxes lyrically on goodness and love, before being overcome with a need to be cruel. His words reduce Liza to utter despair, after which he again feels a need to seek forgiveness. He asks Liza to visit him in his underground hovel. Within a few days, she appears, proving to be a compassionate listener as the Underground Man unloads his troubles on her. Faced with such a giving nature, his own sense of self-worth is again undermined and he cannot resist another urge to be cruel. Liza leaves and he is once more left to rue his actions, his notes providing a means for punishment as he reflects on the pain he has both suffered and inflicted (pp. 80-119).

By comparison with Notes from Underground, 'The Dream of a Ridiculous Man' is more conventional in its structure but no less striking in its content. The story begins with the key character, again unnamed and known merely as the Ridiculous Man, describing his own ridiculousness and declaring his wish to commit suicide. He claims that whatever he did, it would 'make no difference' (Dostoevsky, 1997, p. 297). Weeks go by while he waits for the right moment and having decided finally on a night to commit the deed, he is interrupted in the street by a young girl who pleads with him for help. The Ridiculous Man infers from the girl's actions that her mother is in urgent need of attention, but he does not want to become involved. He suggests that she find a policeman but the girl, desperate for assistance, gives up on the Ridiculous Man and rushes towards another person on the street. Troubled by this experience and aware also of noise in the apartment next to him, the Ridiculous Man nonetheless remains firm in his resolve to kill himself. A revolver at the ready, he sits down but after some time falls asleep.

Unable to kill himself while awake, he does so in a dream. In his dream he is buried but his coffin is later opened and he is taken away by a mysterious being, who carries him for what seems like many thousands of kilometres through space. He eventually finds himself on a planet much like our earth, where he encounters a group of people living in an apparent paradise. The physical environment is wondrous, with tall trees, glittering grass, resplendent flowers, birds flying freely and fearlessly, and waves lapping gently against the sea shore. The people he finds there live in complete harmony with their surroundings and with each other. They sing, play and work together happily. They all share in child rearing duties. They do not feel envy, anger, sorrow, or shame. They have no knowledge of deceit or hatred and exist in a state of total love with all that exists. They have no science but instead have a form of higher understanding, where they know how to live without the need for a science of life.

This purity of this utopian bubble is punctured dramatically, however, by the Ridiculous Man himself, who, by his own assessment, brings about the Fall of his blissful companions on the other earth. Millennia pass but eventually the corrupting influences so prevalent in his original earthly home come into being: lies, resentment, cruelty, factionalism, and fighting. Crime appears and laws become necessary. From the innocence of love for all, people now separate themselves from each other, 
speaking different languages, building new alliances, and seeking solace in forms of religious observance that had previously not been needed. The strong dominate the weak. There is much suffering and people find it difficult to recover the happiness that had earlier prevailed.

The Ridiculous Man loves his companions all the more for their suffering but is full of remorse for what he has done. He asks to be crucified but the people do not allow this. In time, he is considered dangerous and is threatened with the madhouse. This fills him with such sorrow that he suddenly awakens from the dream. He finds himself in the chair where he had sat down to kill himself and immediately pushes the revolver away in horror. He now wishes, more than ever before, to live - and to tell others of the truth he has seen in his dream. He is ridiculed by others for his preaching but is unswerving in his conviction that happiness and beauty can be created on earth, if only human beings can follow the simple principle of loving others as themselves. He finds the little girl again and affirms his intention to go on.

\section{Consciousness, despair and education}

There is no love of life without despair of life.

- Albert Camus (1968, p. 56)

The connection between Notes from Underground and 'The Dream of a Ridiculous Man' is pivotal in understanding the fundamental energies at work in Dostoevsky's fiction. When Dostoevsky wrote Notes from Underground, it was as if he had suddenly found the voice he had been looking for all his writing life. In the Underground Man we find, for the first time, the coiled tensions, contradictions and frailties of the Dostoevskian individual on display, vividly and dramatically. In this short novel we also see the brutality of human relations, the alienation that characterises many lives, and the sense of loss and longing that would figure so prominently in Dostoevsky's later work. We find that the human being is not one but many, and discover that our knowledge not only of the world but of ourselves will inevitably fall short of what we regard as ideal. Wrapped up in the Underground Man - in his expressed beliefs, his circumstances, and the events he describes - is everything that was to give Dostoevsky's work its literary power.

The Ridiculous Man needs to be seen as the Underground Man's brother perhaps even an unidentical twin. These two characters differ from each other in some important respects, but there are definite family resemblances: both are 'outsiders'; both have a kind of hyper-consciousness of themselves and their surroundings; both wish to reach out to others (even if this is not evident at first glance) but struggle to do so effectively. Perhaps most notably, given the focus of this paper, both the Underground Man and the Ridiculous Man live in despair. Their lives are filled with a sense of disgust as they examine themselves and the world. The Underground Man is the very embodiment of unhappiness - a thoroughly miserable creature, destined, it seems, to live with his sense of failure and his alienation from others for the rest of his days. The Ridiculous Man, initially on the brink of ending it all, discovers through his dream what appears to be absolute happiness: a group of people for whom all is light and joy, living free of worries, full of love for each other and for their world. From this encounter, his own life finds renewed sustenance, and the Ridiculous Man has a fervent desire to teach others about the secret of the happiness he has found. This state of innocence and happiness may, however, also be 
a condition of despair. In The Sickness unto Death, Kierkegaard (1989) maintains that even those who appear to be furthest from despair may in fact be in despair. ${ }^{5}$ The heart of happiness, Kierkegaard argues, can be despair's 'choicest dwelling-place' (p. 55). 'A sense of security and repose', similarly, 'may mean that one is in despair' (p. 54):

Even what is humanly speaking the most beautiful and loveliest thing of all - a womanly youthfulness which is sheer peace and harmony and joy - is nevertheless despair. For while it can be counted the greatest good fortune, good fortune is not a specification of spirit, and deep, deep inside, deep within good fortune's most hidden recesses, there dwells also the dread that is despair. (p. 55)

What is it that is missing in the apparently perfect world encountered by the Ridiculous Man? I would argue that it is the impulse to life. The basis for the tranquillity and harmony that prevails among the pre-corrupted other earth dwellers is their absolute integration with each other and with the rest of nature. This can be seen as a form of death. Separation of a certain kind, painful as this is, is necessary for life. The beginnings of this separation lie in something that makes us distinctively human: our capacity for reflective consciousness.

Dostoevsky believed that the origin of consciousness was suffering. He saw suffering as necessary for anyone wanting to write well (see Pevear, 2002, p. 497), and he showed repeatedly, through his portraits of key characters, that suffering played a key role in the development of a heightened sense of self-awareness. Yet, the reverse is also true: consciousness is the origin of suffering. A pivotal element in the Fall of the idyllic other earth dwellers - and it must be remembered that the Fall is initiated by the Ridiculous Man - is their loss of innocence and the emergence of a new form of consciousness. They start to theorise, to invent ideas and concepts, to critique their former mode of life. Science and laws and slavery arrive. With these changes, suffering arises. However, far from wanting to deny this, the people come to love their sorrow. They reach the very position Dostoevsky himself articulated in describing the creative process: they seek suffering and come to believe that 'truth is attained only through suffering' (Dostoevsky, 1997, p. 314). ${ }^{6}$

In seeking to understand the relationship between consciousness and suffering, Unamuno (1972) is particularly insightful:

Suffering is the way of consciousness, and it is through suffering that living beings achieve self-consciousness. To possess consciousness of oneself, to have personality, is to know and feel oneself distinct from other beings. And this feeling of distinctiveness is reached only through a collision, through more or less severe suffering, through a sense of one’s own limits.

\footnotetext{
${ }^{5}$ To better appreciate Kierkegaard's position, we would need to examine his other works, particularly those where the themes of despair and dread figures prominently such as Either/Or (Kierkegaard, 1987) and The Concept of Anxiety (Kierkegaard, 1980), but also the philosophical overviews provided in Philosophical Fragments (Kierkegaard, 1985) and Concluding Unscientific Postscript (Kierkegaard, 2009), together with the 'inspirational' writings such as Stages on Life's Way (Kierkegaard, 1988) and Works of Love (Kierkegaard, 1998). Such an exploration is, however, beyond the scope of the present paper. Helpful analyses of Kierkegaard's account of despair can be found in Kosch (2006), McKnight (2004) and Nielson (2006).

${ }^{6}$ Of course, suffering and despair are not equivalents, though they are closely related to each other. Despair might be seen as a specific form of suffering: a state that persists for some time, as a kind of shadow that accompanies a person. One of the respondents to this paper, Frédérique Brossard Børhaug, put it beautifully when she described despair as an 'ethical backlight' in a human life: something that remains present throughout but which does not necessarily prevent us from also experiencing moments of happiness. What Dostoevsky and Unamuno have to say about suffering also applies to despair as it is understood in this paper.
} 
Consciousness of oneself is simply consciousness of one's own limitation. I feel that I am myself when I feel that I am not others; to know and feel the extent of my being is to know where I cease being, the point beyond which I no longer am. (p. 154)

Unamuno goes on to ask: 'How would one know one existed unless one suffered in some measure? How turn inward, achieve reflective consciousness, unless it be through suffering?' (p. 154). In pleasure, he says, we forget ourselves - forget our own existence. This, for Unamuno, is not a form of liberation but a process of alienation - of literally becoming an alien being. Thus, while we might acknowledge the alienation from other selves suffered by the Underground Man and the Ridiculous Man, if Unamuno is right the blissful inhabitants of the other earth are alienated from themselves - from the distinctive attributes that affirm their existence as human beings. For Unamuno, reflective consciousness - knowing that we know - is a disease, but one from which we cannot escape (p. 22). Existentially, we must live with this sickness, just as the body learns to accommodate the germs of a physical disease. The idea of health is, as Unamuno sees it, an abstract category - an impossibility - but if this were not so, 'we might say that a perfectly healthy man would no longer be a man but an irrational animal: irrational for want of any disease to ignite his reason' (p. 25).

We often think of despair as something to be avoided, perhaps more so than almost anything else, yet it is possible to not only accept despair but to embrace it as a stroke of good fortune. This is not in any way to diminish or deny the pain experienced by those in despair, nor to advocate that we impose despair on others 'for their own good'. It is rather to recognise that if we are to humanise ourselves - and I am using this term rather narrowly in this context to mean realising our capacity for reflective thought - despair is inevitable. ${ }^{7}$ It is the way we work with despair, and allow it to work on us, that is crucial in pedagogical terms. As Kierkegaard (1989) observes, while the actual experience of despair is, on multiple levels, horrific, in the possibility of despair we find what is most deeply human about us (pp. 44-45). Of despair as an illness, an ailment we all face, Kierkegaard believes we can say this: 'it is truly providential to get it, even though it is the most dangerous of sicknesses if one does not want to be cured of it' (p. 56). ${ }^{8}$ Here I think Kierkegaard is only partially right. This is a sickness that defines us as human beings and it is potentially a dangerous disease. It seems to me, however, that we do not have to think of wanting

\footnotetext{
${ }^{7}$ I am not suggesting that reflection constitutes the whole of the humanisation process but simply noting that it is an important part of it. For a broader account of humanisation, see Roberts (2000).

${ }^{8}$ Kierkegaard's concept of despair is also linked to the question of choice. In recent decades, with neoliberalism in the ascendency, the notion of choice has been denuded of much of its original existential force. Unlike neoliberals, for whom the question of choice is largely limited to consumer style preferences in the market, Kierkegaard speaks of choosing in relation to modes of life. Our experience of despair is, in part, dependent upon the extent to which, and the ways in which, we choose the self that we become. For Kierkegaard, choice is a key element in distinguishing between aesthetic, ethical and religious forms of life. The aesthetic mode, centred on the idea of gaining pleasure from external objects, does not involve the authentic creation of a self. For the aesthete, '[n]o genuine choice is made because nothing significant happens. One's inherent need for transcendence and meaning is repressed. The outcome is a pervasive feeling of estrangement, melancholy and despair' (Golomb, 1992, p. 76). The ethical sphere involves reflective commitment but, in its reliance on abstract and universalist principles, 'depersonalizes the self, suppressing spontaneous, passionate selfexpression' and thus prevents the human being from forming him- or herself as a unique individual (p. 76). In this realm, one becomes wracked with guilt in being unable to live up to ethical ideals and also falls into despair. The ethical stage prepares the way, however, for authentic faith: the risky, uncertain, passionate choice to create one's true self, inwardly rather than merely externally, in the religious life (pp. 76-78).
} 
to be cured of despair as an illness. And the basis for objecting to this characterisation of despair - as something that must be cured or overcome - does not have to be discomfort with the theistic nature of Kierkegaard's solution; rather, it is the very notion that a cure is necessary or possible. I shall try to show that despair is not a condition for which a cure can be found; rather, we must learn to live with it, and this is one of the key elements of educational development.

If education is, among other things, a process a deepening understanding - of extending and enhancing consciousness - some searching ethical questions arise, particularly for those of us who work as teachers. For it is not merely a matter of recognising that we all suffer from despair; it is also necessary to acknowledge that we may play a role in increasing despair among those we teach. In fostering the development of a reflective or critical consciousness, we also open up the possibility of greater suffering. ${ }^{9}$ Kierkegaard warns us: 'It is the rising level of consciousness, or the degree to which it rises, that is the continual intensification of despair: the more consciousness the more intense the despair' (p. 72). This helps us to understand why the Underground Man suffers so acutely (he sees himself as more educated than those with whom he interacts and his hyper-consciousness is in evidence throughout), and we may appreciate Kierkegaard's point by reflecting on our own educational experiences. But do we have a right as teachers to risk inflicting such suffering on others?

There is no simple answer to this question. One way to respond is to say that temporary suffering is necessary if later benefits are to accrue. Acceptance of a version of this line of argument is commonplace. We often believe, for example, that the stress involved in completing school tasks - assignments, examinations, and the like - over many years will find ample compensation in the opportunities to attend university and secure a better job than would otherwise be the case. Or, we support the idea of children undergoing years of arduous practice in learning a musical instrument on the grounds that they will be grateful for having been pushed in this way by the time they reach adulthood. The notion of 'no pain, no gain' is also routinely applied when seeking to improve ourselves physically, by, for instance, beginning a running programme or joining a gym.

Yet, it seems to me that there is something unsatisfactory in these forms of justification, at least when it comes to examining despair and its relation to education. There is an instrumentalist logic lurking in the background here, where it is assumed that there is an endpoint of some kind: the 'reward' for the suffering. The experience of despair is, however, arguably something from which we can never fully escape. This applies especially when we think of the role education plays in deepening our consciousness, and thereby, in Kierkegaard's and Unamuno's terms, heightening our sense of despair. The despair of education lies, at least partially, in not being able to go back. Short of being subject to sophisticated techniques of 'brainwashing', or of being drugged into stupefaction, or of developing a brain altering illness (such as Alzheimer's disease), we cannot 'unlearn' what has already been acquired. I am not talking here of factual information (that might easily be forgotten as the years pass) but rather of qualitative changes in our being - states of mind, ways of thinking, forms of emotional development that emerge, gradually but surely, through the process of educational formation. We may find, for example, that our enjoyment of certain types of entertainment will diminish as we come to recognise their relative shallowness; or,

\footnotetext{
${ }^{9}$ I shall use the terms 'reflective' and 'critical' interchangeably in this paper, mindful however of the fact that they need not be seen as equivalents in all contexts.
} 
we may experience greater distress when watching the news, feeling more intense anger at reports of corruption or exploitation, or more sadness and compassion when viewing the effects of natural or humanly created disasters.

If we seek through education to enhance the development of critical, reflective consciousness in students, and we do so effectively, we intervene in their lives in a way that will leave a permanent mark. We risk playing a direct or indirect role in making those students unhappy, not merely for short periods in classrooms but in the very way they think about themselves, and the world, in their everyday activities thereafter. If instrumentalist justifications for an intervention of this kind are inadequate, a more promising line of defence might be to draw a comparison with some of the alternatives. We might say that developing a critical, and in that sense despairing, consciousness is better than deliberately 'dumbing down' the curriculum or simply seeking to pump facts into students' minds. Apart from being undesirable in themselves, we could argue, such approaches bring a host of other negative consequences. A pedagogical system that works against the formation of critically conscious beings allows social injustices to continue without contestation, undermines notions of informed consent in decision making situations (e.g., at the polling booth, or in a hospital), and closes off the possibility of new forms of experience that demand greater intellectual sophistication.

Even here, though, there is a sense that something of the spirit of Dostoevsky's, Kierkegaard's and Unamuno's work has been lost. These thinkers are so effective in portraying, in their different ways, the tragedy of the human condition because they recognise the tensions, the uncertainties associated with processes of human becoming. It is true that both Dostoevsky and Kierkegaard ultimately settled on faith-based ethical preferences, but neither did so without experiencing first-hand the deep-seated tensions portrayed so effectively in their published works. Dostoevsky, I believe, remained conflicted in his thinking about God and morality (see further, Kelly, 1988; Roberts, 2005), and with Kierkegaard, a master of literary seduction (Sæverot, 2011), we cannot even be certain of who the 'real' author is. Indeed, we are wrong to seek one, and should simply let the different voices of his various pseudonyms work on us as Kierkegaard, or the multiple Kierkegaards, hoped they might. Kierkegaard was, in one sense, profoundly honest in his philosophical labours - probing, with great courage, where few before him had dared to go - but he was also deceptive. Never being able to quite 'pin him down', to ascertain his 'true' views, may be exasperating, but it can also have pedagogical value. Deceit, as Sæverot (2010) has argued, can be educative.

What these thinkers, and many others in the existentialist tradition, have to teach us is that we can never uncover all the mysteries of reality, never be sure of the moral ground on which our actions are based, never fully know ourselves. Education, I suggest, is also like this: it allows us not to become more confident in our answers to some of life's deepest riddles but more appreciative of how much we do not know. In this respect, we are much indebted to a line of thinkers stretching back, in the West, at least as far as Socrates. Becoming less certain of our certainties, as the influential Brazilian educationist Paulo Freire recognised, does not mean we need to be any less committed to social action and the ideal of building a better world (Freire, 1994, 1997, 1998; Roberts, 2010). Unamuno, in describing the nature of his own work, takes a similar stance:

Whoever perseveres and reads on will see how, out of this abyss of despair, hope my emanate, and how this crucial point may serve as [a] source for human, profoundly human, effort and action, may serve the cause of solidarity and even of progress. The reader who perseveres and 
reads on will discover a pragmatic justification. And he will see that to work and to be morally effective there is no need to count on either of the two opposed certitudes, no need to depend on the certainty of faith or the certainty of reason, and even less need to evade - ever the problem of the immortality of the soul, or to distort it idealistically, that is, hypocritically. The reader will see that this uncertainty, the suffering, and the fruitless struggle to escape uncertainty, can be and are a basis for action and a foundation for morals. (pp. 141-142)

In pondering what this mode of thinking might mean for suffering and education, Simone Weil (1997) is helpful: we should, she says, love suffering because it is, not because it is 'useful' (p. 131). This implies that the problem of suffering is ontological, ethical and educational. Dostoevsky, Kierkegaard and Unamuno show that to be human is to suffer - to experience despair. We are suffering (an ontological proposition), and to love suffering (an ethical task), as Weil counsels us to do, is to love ourselves - that is, commit ourselves to the task of becoming more fully human (an educational matter).

Education, when considered from this starting point, does not provide an escape from suffering but a growing awareness of it. Such an approach differs substantially from the prevailing view described at the beginning of this paper. Education, by allowing us to recognise our own despair as well as the suffering of others, is an unsettling, uncomfortable process. To commit to education takes great courage, for teaching and learning, where they are connected with the development of a critical consciousness, are inherently risky activities. Today, we often seek predictability, and set up elaborate systems of measurement and evaluation to try and ensure we obtain this. We think of education as working with knowledge - with that which is known - but it is, if anything, more a matter of stepping into the unknown. To be educated, and I am speaking here of education as a task rather than an achievement, is to not only accept but actively embrace uncertainty.

Conceived in these terms, education is anything but a smooth, easy process; it is difficult, messy, complex, and necessarily lifelong. Once the process has begun, it cannot be stopped. To be educated is to live, constantly, with tensions - and the most important of those tensions, between hope and despair, can never be resolved. This is what the Underground Man lives out, in a particularly dramatic way. He sits for much of the time scowling and ranting (internally, as well as in his Notes) in his subterranean hovel, the very embodiment of despair, yet he also experiences moments of hope - generated largely but not exclusively by his encounters with Liza. He has, despite appearances to the contrary, started on a process of what we might refer to as educative redemption. The Notes themselves are an important part of this process, providing a means for reflection and a 'purging' of distressing thoughts. The Underground Man who composes the Notes is fifteen or sixteen years the senior of the younger one he describes in Part Two of the book. That older man, as Rosenshield (1984) shows, takes full responsibility for his earlier actions, experiencing guilt for them but also becoming more genuinely compassionate as he reflects on his relations with Liza.

The Underground Man's commitment to others is hampered by his egoism and pride, yet he has a nuanced, complex understanding of himself. The Ridiculous Man has a fervent wish to pass on his newly discovered truth to others, but has further work to do in comprehending the circumstances that led to his initial suicidal thoughts. The Underground Man is aware of his despair yet perhaps not as fully cognisant of how far he has come, by the time he authors his Notes, in addressing this. 'Addressing' it does not mean overcoming it but reflecting upon it, accepting it, and responding to it. The Ridiculous Man, by the end of his tale, lives on more peaceful 
terms with himself than is the case with the Underground Man, but this is in part because he has not faced up fully to himself and his despair. His solution to his despair is based purely on revelation, but the content of the dream itself suggests more than this will be needed. His dream is a step along the way in that process, but in his new vocation of preaching - of conveying the truth he has found - he may discover that through the act of teaching others, he also learns from them. Of pivotal importance, both the Underground Man and the Ridiculous Man go on, and this, to use Kierkegaard's phrase but in a different way, is the 'leap of faith' we all must take if we commit ourselves to the process of education. With education, we risk it all every time we seek to teach or to learn: we risk overturning what we think we know, undermining our values and beliefs, severing our sense of security and our reason for being. The uncertainty, the unpredictability, of education is what makes it both a source of despair and a source of hope.

\section{Conclusion}

Where does this leave us in thinking about happiness and education? If the ideas considered in this paper have any weight, our obsession with happiness as the 'resolution' to all of life's difficulties must be seen as misguided. This is not to suggest that happiness is unimportant; nor does it imply a position 'against' happiness. Happiness, for most of us, is a vital component of a good life - but it need not be the goal to which we should always aspire. We can experience happiness in a multitude of different ways, many of which have little or no connection with dominant constructions of 'the happy life'. Education has a key contribution to make in highlighting some of those possibilities. There is much that could be done, also, in exploring the myriad ways in which teaching and learning can themselves become joyous activities. But this need not deter us from facing up to the question of despair.

Despair is not a temporary medical condition but a defining feature of human existence. The screams of despair that characterise human lives cannot be 'drowned out' with healthy doses of happiness. As Kierkegaard argues, even those who appear most happy, most content, may nevertheless be in despair. The genesis of despair, Dostoevsky and Unamuno show, lies in our capacity for reflective consciousness. Education, to the extent that it enhances the development of this distinctively human quality, is thus complicit in the promotion of despair. We cannot escape from despair but must learn to live with it. ${ }^{10}$ Despair need not provide a reason for inaction or indifference; to the contrary, it can serve as the basis on which a passionate commitment to life may proceed. Education, as it has been interpreted here, does not make us happier but it can enable us to more deeply understand the suffering we and others experience. Happiness in its commodified form, as a kind of drug to be marketed and administered in regular doses, takes us not closer to our humanity but further away from it. Education has a critical role to play in allowing us to go on accepting the risk of unhappiness, of uncertainty, and of continuous change.

\footnotetext{
${ }^{10}$ This does not imply the abandonment of hope; quite the opposite, in fact. While it is true that despair can be understood as a state of being or a situation 'without hope', it is also possible to see despair as the very condition that gives hope substance and meaning. Hope, as it were, 'comes into its own' when despair is identified, understood and addressed. Hope and despair, as Paulo Freire (1972, 1994, 1997, 1998) showed, are intimately connected. Expressions of hope in times of relative harmony and prosperity can sometimes appear somewhat empty. It is when circumstances are most desperate that hope is needed more than ever.
} 


\section{Acknowledgements}

An earlier version of this paper was presented at the $3^{\text {rd }}$ Annual Bergen Educational Conversation, University of Bergen, 21-22 September 2011. I would like to thank other participants at this event for their helpful comments. I am especially grateful to Frédérique Brossard Børhaug and Herner Sæverot, who served as respondents to my paper. Further valuable feedback was received via the journal's reviewing process.

\section{References}

Barrett, W. (1990). Irrational man: A study in existential philosophy. New York: Anchor Books.

Camus, A. (1968) Love of life. In A. Camus, Lyrical and critical essays (E.C. Kennedy, Trans.) (52-57). New York: Vintage Books.

Chernyshevsky, N.G. (1989). What is to be done? (M.R. Katz, Trans.). Ithaca, NY, and London: Cornell University Press.

Cooper, D.E. (1999). Existentialism: A reconstruction, $2^{\text {nd }}$ edn. Oxford: Blackwell.

Dostoevsky, F. (1991). The brothers Karamazov (R. Pevear \& L. Volokhonsky, Trans.). New York: Vintage.

Dostoevsky, F. (1993). Crime and punishment (R. Pevear \& L. Volokhonsky, Trans.) London: Vintage.

Dostoevsky, F. (1994). Demons (R. Pevear \& L. Volokhonsky, Trans.). London: Vintage.

Dostoevsky, F. (1997). The dream of a ridiculous man. In F. Dostoevsky, The eternal husband and other stories (R. Pevear \& L. Volokhonsky, Trans.) (296-319). New York: Bantam Books.

Dostoevsky, F. (2001). The idiot (R. Pevear \& L. Volokhonsky, Trans.). London: Granta.

Dostoevsky, F. (2004). Notes from underground (R. Pevear \& L. Volokhonsky, Trans.). New York: Everyman's Library.

Dostoevsky, F. (2009). A writer's diary (K. Lantz, Trans.). Chicago, IL: Northwestern University Press.

Flynn, T. (2009). Existentialism: A brief insight. New York: Sterling.

Frank, J. (2010). Dostoevsky: A writer in his time. Princeton, NJ: Princeton University Press.

Freire, P. (1972). Pedagogy of the oppressed. Harmondsworth: Penguin.

Freire, P. (1994). Pedagogy of hope. New York: Continuum.

Freire, P. (1997). Pedagogy of the heart. New York: Continuum.

Freire, P. (1998). Pedagogy of freedom: Ethics, democracy, and civic courage. Lanham, Maryland: Rowman and Littlefield.

Golomb, J. (1992). Kierkegaard's ironic ladder to authentic faith, International Journal for Philosophy of Religion, 32(2), 65-81.

Kaufmann, W. (Ed.) (1975). Existentialism from Dostoevsky to Sartre. New York: Plume.

Kelly, A. (1988). Dostoevskii and the divided conscience. Slavic Review, 47(2), 239260. 
Kierkegaard, S. (1980). The concept of anxiety (R. Thomte with A.B. Anderson, Trans.). Princeton, NJ: Princeton University Press.

Kierkegaard, S. (1985). Philosophical fragments (H.V. Hong \& E.H. Hong, Trans.). Princeton, NJ: Princeton University Press.

Kierkegaard, S. (1987). Either/or, 2 vols. (H.V. Hong \& E.H. Hong, Trans.). Princeton, NJ: Princeton University Press.

Kierkegaard, S. (1988). Stages on life's way (H.V. Hong \& E.H. Hong, Trans.). Princeton, NJ: Princeton University Press.

Kierkegaard, S. (1989). The sickness unto death (A. Hannay, Trans.). London: Penguin.

Kierkegaard, S. (1998). Works of love (H.V. Hong \& E.H. Hong, Trans.). Princeton, NJ: Princeton University Press.

Kierkegaard, S. (2009). Concluding unscientific postscript (A. Hannay, Trans.). Cambridge: Cambridge University Press.

Kosch, M. (2006). 'Despair' in Kierkegaard's Either/or. Journal of the History of Philosophy, 44(1), 85-97.

Liston, D. (2000). Love and despair in teaching, Educational Theory, 50 (1), 81-102.

Magarshack, D. (2001) Introduction, in: F. Dostoevsky, The Best Short Stories of Fyodor Dostoevsky, ix-xxiii (New York, The Modern Library).

Marino, G. (Ed.) (2004). Basic writings of existentialism. New York: The Modern Library.

McKnight, D. (2004). Kierkegaard and the despair of the aesthetic existence in teaching. Journal of Curriculum Theorizing, 20(1), 59-80.

Nielsen, K. (2006) The negativistic process of education, Nordic Psychology, 58 (3), 183-195.

Noddings, N. (2003) Happiness and Education (Cambridge, Cambridge University Press).

Pevear, R. (2002). To find the man in Dostoevsky. The Hudson Review, 55(3), 495503.

Roberts, P. (2000). Education, literacy, and humanization: Exploring the work of Paulo Freire. Westport, CT: Bergin and Garvey.

Roberts, P. (2005). Freire and Dostoevsky: Uncertainty, dialogue and transformation. Journal of Transformative Education, 3(2), 126-139.

Roberts, P. (2010). Paulo Freire in the $21^{\text {st }}$ century: Education, dialogue and transformation. Boulder, CO, and London, UK: Paradigm Publishers.

Roberts, P. (2012). Education and the limits of reason: Reading Dostoevsky. Educational Theory, 62(2).

Rosenshield, G. (1984). The fate of Dostoevskij's Underground Man: The case for an open ending. The Slavic and East European Journal, 28(3), 324-339.

Sæverot, H. (2010). Educative deceit: Vladimir Nabokov and the (im)possibility of education. Educational Theory, 60(5), 601-619.

Sæverot, H. (2011). Kierkegaard, seduction and existential education. Studies in Philosophy and Education, DOI: 10.1007/s11217-011-9239-6, 1-16.

Scanlan, J.P. (2002). Dostoevsky the Thinker. Ithaca, NY: Cornell University Press.

Unamuno, M. de (1972). The tragic sense of life in men and nations (A. Kerrigan, Trans.). Princeton, NJ: Princeton University Press.

Weil, S. (1997). Gravity and grace (A. Wills, Trans.). Lincoln: Bison Books. 